\title{
SETENTA ANOS DEPOIS: DIREITOS AUTORAIS EM NOEL ROSA
}

Daniel do Amaral Arbix

SEVENTY YEARS LATER: NOEL ROSA'S COPYRIGHTS

\section{RESUMO}

UM REGIME ÓtIMO DE DIREITOS AUTORAIS, AO TOMAR FUNDAMENTO NO ESTÍMULO AO DESENVOLVIMENTO DE NOVOS BENS INTELECTUAIS, DEPENDE DE LIMITES BEM TRAÇADOS. ESTE ARTIGO PROCURA AFERIR A FUNCIONALIDADE DESSES DIREITOS NO QUE DIZ RESPEITO A COMPOSIÇÕES MUSICAIS, DE SORTE A AVALIAR, NESSE CAMPO ESPECÍFICO, A MALEABILIDADE DA PROTEÇÃO AOS DIREITOS AUTORAIS E SUA ADEQUACCÃO À CRIAÇÃO DE NOVAS OBRAs. PARA TANTO, REMETE-SE À EXPERIÊNCIA CRIATIVA DE E SOBRE NOEL ROSA, EXPOENTE dO SAMBA BRASILEIRO. A MARCADA ASSUNÇÃO DE RISCOS POR AUTORES DE OBRAS DERIVADAS, A FORMALIZAC̣ÃO IRREGULAR DAS RELAC̣ÕES JURÍDICAS ENTRE TITULARES DE DIREITOS AUTORAIS E A PROFISSIONALIZACÃO DE DETERMINADOS AUTORES SÃO CONSTATADAS COMO RESPOSTAS DIRETAS AOS INCENTIVOS LEGAIS PERTINENTES. A INCERTEZA DECORRENTE DESSAS RESPOSTAS EXPÖE A DESSINTONIA ENTRE ALGUNS DOS OBJETIVOS DAS NORMAS ANALISADAS E SEUS EFEITOS PRÁTICOS.

\section{PALAVRAS-CHAVE}

DIREITO AUTORAL, DOMÍNIO PÚBLICO, OBRA INTELECTUAL, DIREITO MORAL DO AUTOR

\begin{abstract}
AN OPTIMAL COPYRIGHT REGIME, BASED ON FOSTERING THE DEVELOPMENT OF NEW INTELLECTUAL WORKS, DEPENDS ON WELL DESIGNED LIMITATIONS. THIS ARTICLE AIMS TO ANALYZE SUCH RIGHTS' FUNCTIONALITY WITH RESPECT TO MUSICAL WORKS, IN ORDER TO EVALUATE, IN THIS FIELD SPECIFICALLY, THE FLEXIBILITY OF COPYRIGHT PROTECTION AND ITS ADEQUACY FOR THE CREATION OF NEW WORKS. TO PERFORM SUCH TASK, THE CREATIVE PROCESS OF BRAZILIAN SAMBA EXPERT, NOEL ROSA, IS EXAMINED. A REMARKABLE ASSUMPTION OF RISKS BY DERIVATIVE WORKS' AUTHORS, THE IRREGULAR FORMALIZATION OF LEGAL RELATIONS BETWEEN COPYRIGHT OWNERS AND THE PROFISSIONALIZATION OF CERTAIN AUTHORS ARE SEEN AS DIRECT ANSWERS TO THE LEGAL INCENTIVES CURRENTLY IN FORCE. THE UNCERTAINTY DERIVED FROM SUCH ANSWERS EXPOSES THE TENSION BETWEEN SOME OF THE ANALYZED NORMS' OBJECTIVES AND THEIR ACTUAL EFFECTS.

\section{KEYWORDS}

COPYRIGHT, PUBLIC DOMAIN, INTELLECTUAL WORK, AUTHOR'S MORAL RIGHTS
\end{abstract}

\section{INTRODUÇ̃̃O}

Os direitos de propriedade intelectual conferem uma artificial exclusividade às criações imateriais, nelas inserindo o elemento da escassez, próprio do mundo concreto (Barbosa, 2003, p. 70-71). Essa resposta jurídica dirige-se a um problema econômico - os bens intelectuais, não-exclusivos e não-concorrentes, geram externalidades 
positivas. Falhas de mercado capazes de beneficiar free riders e desestimular o desenvolvimento de novos bens intelectuais.

Para que haja estímulo à atividade criativa, tais direitos procuram internalizar parte do benefício social decorrente dos bens intelectuais (LEMLEY, 2005, p. 1032; LANDES; POSNER, 2003a, p. 24). Contudo, o regime brasileiro de direitos autorais, voltado ao progresso das manifestações de espírito, revela-se muitas vezes inadequado para conduzir textos, músicas e pinturas, entre outros, ao melhor aproveitamento social. Permite, por exemplo, que criações coletivas sejam apropriadas inadvertidamente, mas também que os contornos muito marcados da exclusividade sobre obras intelectuais as releguem ao esquecimento, ou que sejam impedidos usos e recriações legítimos, aprimoramentos e transformações inevitáveis, confrontos e misturas geniais.

Nos últimos 70 anos, assim como durante a vida de Noel de Medeiros Rosa, morto em 4 de maio de 1937, a utilização de suas melodias e letras esteve sujeita a fortes amarras jurídicas, primeiro do Código Civil, e, depois, tanto da antiga Lei $\mathrm{n}^{\circ}$ 5.988/73 quanto da vigente Lei de Direitos Autorais (Lei n ${ }^{\circ}$ 9.610/98). Este artigo busca recompor momentos de brilho do sambista - acompanhado por um semnúmero de outros autores, conhecidos ou não -, dissecando os potenciais riscos para as criações musicais e ilícitos relacionados a direitos autorais. Pretende-se expor, à luz de alguns dos sambas mais notáveis da memória musical brasileira, as ameaças que pairam sobre as obras intelectuais já existentes e a lúgubre sombra que avança sobre as futuras.

Uma vez descrito o eixo normativo dos direitos autorais - a exclusividade conferida sobre a obra intelectual -, será detalhada a proteção sobre composições musicais. Na seqüência, será exposto o contexto criativo do samba, para, então, abordar os diálogos nos quais a obra de Noel Rosa prepondera. A partir desses exemplos, a dinâmica da utilização livre de obras intelectuais será discutida tanto durante a vigência dos direitos autorais quanto após seu esgotamento.

\section{A Proteção Autoral - eXclusividade}

“A Vila é uma cidade independente

Que tira samba mas não quer tirar patente.”

Palpite infeliz, 1935, Noel Rosa.

Os direitos autorais cumprem um propósito simples: garantem a seus titulares a prerrogativa da exclusividade sobre os bens intelectuais (ASCENSÃO, 1980, p. 85). Não obstante o trabalhador intelectual por vezes se satisfazer com o reconhecimento e a gratidão por sua criação e alcançar satisfação estética sobre o produto de seus 
esforços, somente com essa exclusividade lhe é assegurado "o proveito material, consistente no resultado pecuniário que possa colher de seu trabalho" (CERQUEIRA, 1946, p. 68).

A exclusividade denota a funcionalidade desses direitos (BARBOSA, 2003, p. 22). Com a possibilidade e a expectativa de retribuição, objetiva-se incentivar potenciais autores a criar, ampliando e aprofundando as ciências e as artes. O autor pode, assim, ser remunerado a cada utilização de sua obra (BITTAR, 2005, p. 65). Para isso, a escassez, própria dos bens materiais, é forjada por um regramento dos traços e limites relativos aos bens intelectuais, cuja reprodução é cerceada.

Nesse esteio, o sistema de direitos autorais encorajaria a inventividade humana (por meio de royalties e outras vantagens econômicas) e a conseqüente publicização de maior número de criações intelectuais beneficiaria a sociedade com ganhos em qualidade de vida e enriquecimento econômico e cultural (ASCARELLI, 1970). Os impulsos normativos à atividade criativa, porém, não são o único fundamento para os direitos autorais. O direito natural do homem a suas criações, já presente em Locke (1994, p. 108), motivou abordagem moral dos direitos autorais, que seriam extensão da personalidade humana.

Entretanto, com o primado do titular de direitos, traduzido por uma ênfase em sua "propriedade" e na repressão aos free riders, os benefícios sociais são reduzidos. A restrição ao uso dos bens intelectuais com base na injustiça do enriquecimento ilícito, ou a simplificação econômica de buscar a internalização completa das externalidades positivas geradas por esses bens, acarreta um excesso de proteção, que diminui o bem-estar de todos (LEMLEY, 2005, p. 1059-1065). Por ser uma deficiência sistêmica, essa medida inadequada de prerrogativas não caracteriza abuso de direito; porém, desemboca em inevitáveis atritos relativos à utilização de obras existentes e forte instabilidade no que diz respeito à criação de novas obras. ${ }^{1}$

No Brasil, as justificativas para os direitos autorais combinam a visão conseqüencialista, utilitarista, segundo a qual a sociedade ganha com a atribuição de exclusividade aos autores, com a óptica individualista, que reconhece tal exclusividade como inerente ao trabalho intelectual (UNCTAD-ICTSD, 2003, p. 30). Mescladas, essas premissas fundamentam boa parte da elaboração legislativa na matéria. ${ }^{2}$

Embora comumente rotulados como "propriedade", os direitos autorais possuem dinâmica própria e complexa, em especial porque seus objetos, bens intangíveis, não são naturalmente exclusivos nem concorrentes. Como, a partir da constituição de tais direitos, ocorre a afirmação de determinadas prerrogativas (LOPES, 2000, p. 21), ${ }^{3}$ sua justificação - como instituto "propriedade" ou não - é imprescindível; não apenas para que esses direitos sejam positivados, mas para que sua aceitação pública aconteça sem fortes turbulências.

Transformações sociais e diferenças acirradas sobre a concepção e a implementação dos direitos autorais formam reivindicações que confrontam desenhos 
normativos imprecisos e imperfeições funcionais, das perspectivas moral e econômica. Desse conflito entre os distintos valores e esquemas de incentivos relacionados aos direitos autorais (SILVEIRA, 1997, p. 23) surgem discussões sobre sua necessidade, utilidade e justiça. ${ }^{4}$

\section{DiREITOS SOBRE COMPOSIÇÕES MUSICAIS}

"Eu bem sei que tu condenas

O estilo popular

Sendo as notas sete apenas

Mais eu não posso inventar.”

Mais um samba popular, 1934, Noel Rosa.

Os esforços internacionais para a proteção das obras intelectuais consolidaram suas primeiras diretrizes no final do século XIX, com a preocupação de restringir a utilização de tais obras sem autorização de seus criadores ou titulares secundários. As diferentes legislações nacionais procuraram, a partir de então, atenuar a exclusividade sobre as obras intelectuais, prevendo exceções que equilibrassem a fruição de direitos por particulares e os benefícios sociais resultantes dos bens intelectuais.

No Brasil, às primeiras normas nacionais sobre o tema somaram-se, na década de 1970, os mandamentos da Convenção de Berna. ${ }^{5}$ Após a cristalização dos direitos autorais por cláusula pétrea da Constituição Federal de 1988, ${ }^{6}$ o tratamento dos direitos autorais foi modificado pela Lei $n^{\circ} 9.610 / 98$, que sintonizou a legislação brasileira aos pisos mínimos de proteção dos direitos de propriedade intelectual decorrentes da adesão do País ao Acordo (TRIPs). ${ }^{7}$

O conjunto normativo hoje vigente no País define o objeto da proteção conferida pelos direitos autorais simplesmente como criações do espírito. ${ }^{8}$ Apesar de não se identificar com nenhuma de suas exteriorizações, mas sempre as transcender, "una creación intelectual no puede ser percibida sino a través de su exteriorización material en una cosa o en una energía, aunque sólo sera la energía sonora de la palabra" (ASCARELLI, 1970, p. 265).

Ao longo da história desses direitos, a exclusividade conferida sempre recaiu não sobre as idéias em si, mas sobre determinada expressão delas. O artigo 9.2 do Acordo TRIPs dispõe que "a proteção do direito do autor abrangerá expressões e não idéias, procedimentos, métodos de operação ou conceitos matemáticos como tais", previsão ecoada no artigo 8. ${ }^{\circ}$ da Lei n 9.610/98. Tendo em conta que "não é a idéia que é protegida, mas a sua realização em forma definida" (SILVEIRA, 1987, p. 13), ${ }^{9}$ não são consideradas ilícitas as criações de obras intelectuais diferentes, 
ainda que partam da mesmíssima idéia. Nesse esteio, as "variações sobre um mesmo tema" povoam as artes, das bailarinas de Edgar Degas à recorrência de enredos no campo literário (CALVINO, 1990, p. 270-271), alcançando as Variações Goldberg de Johann Sebastian Bach. ${ }^{10}$

Por causa da necessidade de expressão definida de uma concepção intelectual para que sobre ela sejam conferidos direitos autorais, bem como por conta do caráter abstrato de cada obra intelectual protegida, que se pode materializar sob diferentes roupagens, deve-se atentar para uma peculiaridade da proteção às composições musicais. Além dos direitos autorais, que recaem sobre melodia e letra, associam-se naturalmente a tais obras os direitos conexos de artistas e produtores fonográficos, isto é, seu direito de exclusividade sobre determinada interpretação ou gravação de uma obra musical.

Isso significa que, sobre uma versão de Feitio de oração, sobrepõem-se os direitos autorais, originalmente conferidos a Noel Rosa e Vadico, aos direitos conexos relativos àquela versão específica, por exemplo de Francisco Alves, Castro Barbosa e Orquestra Copacabana. Tendo em vista o objetivo de averiguar os efeitos práticos das normas sobre a criação de novas composições musicais, em que intérpretes e executantes não têm participação necessária, este artigo limitará sua apreciação aos direitos autorais, atribuídos a autores e eventualmente transmitidos a outros titulares. Serão considerados, em especial, os contornos dos direitos de reprodução e de criação de obras derivadas, bem como o direito moral de integridade.

\section{Princípios do SAMba}

“O samba na realidade

Não vem do morro nem lá da cidade

E quem suportar uma paixão

Saberá que o samba então

Nasce no coração.”

Feitio de oração, 1933, Noel Rosa, Oswaldo Gogliano [Vadico].

Destacando-se do maxixe, seu precursor, o samba ensaiou seus primeiros passos no Rio de Janeiro, por influência direta da cultura baiana, herdeira de inúmeras tradições africanas de ritmo, compasso e percussão. Após algumas canções menos célebres, em novembro de 1916, foi registrada na Biblioteca Nacional a música Pelo telefone, que teve enorme sucesso, arrebatando das classes mais pobres à nata da elite carioca. Fruto de sessões de samba no terreiro da Tia Ciata, entre doces baianos, candomblé e celebrações musicais, Pelo telefone teve a maioria das estrofes coletada por Donga, freqüentador habitual da casa, que modificou levemente a letra, com o 
auxílio de Mauro de Almeida, e registrou o resultado. "Com isso, o que ele faz? Inicia a grande fase da canção de Carnaval, dá à palavra 'samba' uma dimensão de sucesso e ressalta, por linhas tortas, a importância da autoria na música popular" (VIANNA, 2004, p. 24).

\section{3.i O Registro de Pelo telefone}

[...] vinha revelar o início do processo de profissionalização dos músicos com talento criador saídos das camadas populares. Era já uma prova da tomada de consciência, por parte desses antigos músicos amadores, da possibilidade de aproveitamento comercial de suas produções pelo teatro de revista, pelos editores de música e pelos fabricantes de discos (Tinhorão, 1998, p. 277).

No entanto, esse processo foi conduzido em nome de um único autor, Donga, que não fez constar na Biblioteca Nacional a autoria coletiva. Já naquela época, se percebia a inadequação da proteção autoral em casos de diluição da autoria (CARBONI, 2003, p. 172-177), com uma tendência de apropriação das obras intelectuais por “organizadores" como Donga - que se intitulou, então, líder do processo criativo de Pelo telefone. Ironicamente, mais tarde o mesmo Donga se queixaria de apropriação semelhante por Noel Rosa. ${ }^{11}$

A idéia de autoria estava muito longe de ser a que temos hoje. Mesmo dez, 15 anos depois, quando o samba urbano nascido no Estácio começou a fazer sucesso, vender sambas ou parcerias não era considerada uma atitude absurda pelos compositores. Sinhô, um dos supostamente ludibriados por Donga, foi acusado nos anos seguintes de roubar várias músicas - Heitor dos Prazeres, por exemplo, dizia que eram dele os refrões dos clássicos “Ora vejam só!” (1927) e "Gosto que me enrosco" (1928) - e a ele é atribuída a famosa frase “samba é como passarinho, é de quem pegar” (VIANNA, 2004, p. 25).

Mostra dessa flexibilidade na paternidade intelectual, hoje cristalizada como direito moral do autor (artigo 24, incisos I e II, da Lei $n^{\circ}$ 9.610/98), é a participação de Francisco Alves não só como intérprete, mas também como co-autor ou mesmo único autor dos sambas mais famosos de Ismael Silva, do Estácio:

Como sempre se soube, Chico era um “compositor”, classificação dada pelas línguas ferinas do Café Nice, na Avenida Rio Branco, que remunerava o trabalho alheio em troca da aquisição de parte ou totalidade dos direitos autorais. Mas, igual a ele, havia muitos e muitos. O que o diferenciava da malta é que ele era o cantor de maior sucesso do país” (VIANNA, 2004, p. 45). ${ }^{12}$ 
Os problemas com autoria dos sambas voltariam a se repetir inúmeras vezes, com uma miríade de diferentes compositores. Apropriações de melodias e letras contra a vontade de seus autores ${ }^{13}$ ocorriam em paralelo com as muitas vendas consentidas, a preços os mais variados, ${ }^{14}$ mas também conviviam, e ainda convivem, com criações verdadeiramente coletivas, sem "direção" ou "organização" que esclarecem a quem cabem os direitos autorais, como preconiza a Lei n 9.610/98.

Quando Noel Rosa desfilava no carnaval de Vila Isabel com o bloco Faz Vergonha, por exemplo, compunha o grupo de improvisadores que todos os anos criavam os versos da segunda parte de um estribilho fixo (MÁXIMO; DIDIER, 1990, p. 125-126). Nesse caso, como identificar um autor ou um coordenador das plurais contribuições ao samba do bloco, com reparos, acertos e correções de múltiplas vozes?

Apesar de enriquecer com os frutos desses esforços criativos, no final da década de 1920, a indústria fonográfica apenas engatinhava. As gravadoras, ávidas por ampliar seus catálogos, recorriam a grupos amadores, de classe média, para a fixação de inúmeras composições musicais, nas quais não investiam nada além do material para os discos (MÁXIMO; DIDIER, 1990, p. 102).

Simultaneamente, um bairro do Rio de Janeiro ascendia como ambiente musical privilegiado. Nos tempos do primeiro grupo musical de Noel Rosa, o Bando de Tangarás, a Vila Isabel abrigava também Francisco Alves, Lamartine Babo e uma infinidade de outros "compositores, poetas, cantores, instrumentistas" (MÁXIMO; DIDIER, 1990, p. 143-152). A demanda das gravadoras por novidades foi em parte aplacada pelos músicos da Vila, inclusive pelo Bando de Tangarás. "Mesmo tendo pouca chance de aparecer como autor ou cantor, dada a liderança não muito democrática de Almirante, Noel emplacou algumas criações” (VIANNA, 2004, p. 87). Curiosamente, as primeiras composições de maior alcance do compositor e de sua banda foram emboladas, cocos, cateretês, toadas e desafios, voltadas a aproveitar a moda de músicas nordestinas "tradicionais" no Rio de Janeiro, ainda que criadas e executadas por cariocas (MÁXIMO; DIDIER, 1990, p. 107-113).

É, porém, com a linguagem e a ginga do samba que Noel Rosa verdadeiramente se identificou e nas quais se expressou com genialidade. Ao desenvolver sambas-canções, sambas de partido-alto e outras modalidades, muitas vezes caracterizadas pelo breque (LOPES, 2003), Noel inovou no acompanhamento dos instrumentos e na lírica poética. Conforme Máximo e Didier (1990, p. 130),

[...] já é nítida sua preocupação com a originalidade, não repetir o que os outros já fizeram, não se deixar levar pelos caminhos fáceis do lugar-comum. A partir dessa preocupação, trata de desenvolver logo seus próprios esquemas de fazer música e letra. [...] descobre muito cedo que neste ofício de compositor popular existe como que uma chave, um ponto de partida em todo o processo de criação: a idéia. Noel Rosa começa a ser agora - e será 
sempre - um compositor temático, tudo ou quase tudo partindo de um motivo central, um tema.

\section{Diálogos}

"E este samba que fiz de parceria,

Depois de feito não é dele nem é meu."

Estamos esperando, 1932, Noel Rosa.

Embriagado pelo samba, Noel Rosa vive o início da década de 1930 como músico em tempo integral. Abandonando a faculdade de medicina com rapidez, volta-se a "Cantar o seu bairro, a sua cidade, o seu país. Retratar os personagens que trafegam por aí, focalizar os episódios que testemunha, captar o espírito de tudo isso, eis o destino de Noel Rosa, poeta e cronista” (MÁXIMO; DIDIER, 1990, p. 170). Era inevitável que, em meio às referências ao cotidiano do Rio de Janeiro e do Brasil, surgissem remissões a idéias expressas musicalmente e a outros sambas e sambistas.

Nesse contexto, Noel começou a compor uma série de sambas para Francisco Alves, maior intérprete brasileiro da época, ${ }^{15}$ sem perder de vista a riqueza da musicalidade do morro carioca.

Ao longo de dois, três anos-chave em sua carreira, [...] até se firmar como um cartaz do rádio e do disco já no começo de 1932, Noel vai subir muitas vezes o morro, beber em sua fonte, experimentar parcerias com seus compositores, aprender com eles. Sábia e humildemente [...] [Sua busca] é sobretudo integradora, mais soma que troca, comunhão plena no ato de criar (MÁXIMO; DIDIER, 1990, p. 196).

O autor, da classe média da Vila Isabel, transitou entre as diferentes classes sociais da década de 1930 - ora debatendo com Heitor Villa-Lobos; ora fazendo sambas com o lustrador de móveis Canuto, ora com o jornalista e crítico Orestes Barbosa. Experimentando e integrando melodias, fundindo e repicando letras, Noel propunha sociedades a compositores, letristas e intérpretes, aprimorando versos, sugerindo acompanhamentos, remodelando partes, fazendo em vida 56 parcerias (MÁXIMO; DIDIER, 1990, p. 257-268).

Versos irreverentes aludindo a outras escolas motivaram criações e reações de samba, primeiro com Gargalhada, do Salgueiro (MÁXIMO; DIDIER, 1990, p. 197), depois com Wilson Batista. Esse segundo embate, dos mais profícuos da história do 
samba, foi engatilhado pela resposta de Noel, na música Rapaz folgado, de 1933, à defesa da vadiagem do malandro carioca ${ }^{16}$ feita por Wilson Batista na música Lenço no pescoço, do mesmo ano (DANTAS, 2003). A resposta de Noel valeu-se de elementos figurativos e trechos de versos da composição de Batista, que replicaria com Mocinho da Vila (MÁXIMO; DIDIER, 1990, p. 291-292). O diálogo virulento e explosivo, pouco notado pelos ouvintes dos sambistas, desembocou em uma parceria, o samba Deixa de ser convencida, que selou a paz entre os compositores. Nele, a letra de Noel foi combinada com a melodia de Terra de cego, de Wilson Batista (JUBRAN, 2000, p. 143; MÁXIMO; DIDIER, 1990, p. 421-422).

Se as composições que precederam a parceria oficial dos sambistas fossem consideradas obras em co-autoria, Noel Rosa teria violado os direitos de Wilson Batista - e vice-versa -, visto que "na co-autoria indivisível, o exercício dos direitos depende de acordo entre os interessados, não podendo nenhum deles, sem consentimento dos demais, publicar ou autorizar sua publicação" (BITTAR, 2005, p. 38). Esses diálogos, entretanto, expõem uma possibilidade salutar de reutilizações de elementos de quaisquer obras intelectuais, como se verá adiante.

Outras "conversas", diferidas no tempo, revelam um dinamismo latente nos bens intelectuais. Ao retomar as teses de Noel em Mentir (mentira necessária) e Pra que mentir?, Caetano Veloso reviu melodia e letra daqueles sambas, "atualizando-os" com evidentes acréscimos intelectuais, paralelos ao confronto de conselhos e de visões de mundo. Já Carmem Miranda, ao modificar a letra de Noel na música Tenho um novo amor e interpretá-la à sua maneira, distanciou a obra dos sambas do morro carioca, aportando um novo produto aos salões da alta sociedade fluminense (MÁXIMO; DIDIER, 1990, p. 235).

Mas citações, paráfrases e "respostas" são menos controversas do que efetivas modificações nas obras intelectuais de terceiros, representadas por paródias, traduções e outras obras derivadas e estão longe de esgotar a tradição de transformações típica do samba: a própria Pelo telefone, registrada por Donga, foi parodiada por seus possíveis co-autores, que ironizaram a apropriação da música mesclando a sua melodia os ácidos versos "Ó, que caradura / De dizer nas rodas / Que esse arranjo é teu! / É do bom Hilário / E da velha Ciata / Que o Sinhô escreveu. / Tomara que tu apanhes / Para não tornar a fazer isso. / Escrever o que é dos outros / Sem olhar o compromisso" (VIANNA, 2004, p. 25).

Noel Rosa, ainda jovem, divertia-se com paródias musicais, geralmente inserindo em melodias famosas letras próprias. Máximo e Didier (1990, p. 66-69) relatam transformações de Gigolette (de Franz Lehár), Yes, Sir, that's my baby (de Walter Donaldson e Gus Kahn) e A casinha da colina (de Pedro de Sá Pereira e Luís Peixoto). O lançamento de Noel no samba, ademais, pautou-se em paródias e citações: a letra de sua primeira composição de sucesso, Com que roupa?, substitui com perfeição a do Hino Nacional. ${ }^{17}$ 
A irreverência de Noel foi levemente mitigada pela adaptação da primeira parte da música para que passasse pela censura, mas, embora a melodia hoje conhecida não contenha, nos três compassos iniciais, as mesmas notas do hino, é direta a referência ao "Brasil de Tanga", como dizia o compositor (MÁXIMO; DIDIER, 1990, p. 120121). As derivações não se interrompem nesse ponto: do primeiro trabalho famoso de Noel surgiram propagandas, charges, paródias e até um grupo musical intitulado Com que roupa? (MÁXIMO; DIDIER, 1990, p. 155-163) (VIANNA, 2004, p. 88).

Além disso, na obra do sambista podem ser identificadas diversas outras paródias. Paga-me esta noite é uma paródia de Tell me tonight, de Mischa Spoliansky; Foi ele, parodia Foi ela, de Ary Barroso; Roubou, mas não leva foi construída sobre Ganhou, mas não leva, de Benedito Lacerda e Milton Amaral; Mas como... outra vez? tem o estribilho calcado no Liberstraum n. 3, de Franz Liszt.

Durante as turnês com a banda Ases do Samba, as paródias de Noel no palco exalavam um humor cortante; mais tarde, em projetos para o rádio, especializou-se nos pastiches, que iam de marchinhas e tangos até as óperas de Rossini (MÁXIMO; DIDIER, 1990, p. 224/375-389). Nas viagens a Minas Gerais, improvisando sobre a melodia de I'm looking over a four leaf clover, de Mort Dixon e Harry Woods, Noel criou uma homenagem bem-comportada a Belo Horizonte, cantada em uma festa familiar. Mais tarde, na zona boêmia, revelou outra letra, apimentada e pornográfica (MÁXIMO; DIDIER, 1990, p. 351).

Também são vários os diálogos com sua própria obra. ${ }^{18}$ Paródias de si mesmo como A Genoveva não sabe o que diz, sátira de Palpite infeliz - convivem com recriações majestosas. A maior delas pode ser ouvida em Quando o samba acabou, cuja letra ergueu-se sobre a canção sertaneja Mardade de cabocla, nunca gravada (MÁXIMO; DIDIER, 1990, p. 115-116). Também de um esboço de música e letra, denominado Vou te ripar, Noel fez surgir duas composições diferentes: uma com o mesmo título, Vou te ripar, e outra chamada Nunca... jamais! - esta aproveitando parte da letra original, aquela parte de sua melodia (MÁXIMO; DIDIER, 1990, p. 131-132). Mais tarde, sua marcha Uatch!, preparada para um concurso do jornal Folha de Minas, foi reaproveitada nas composições Morena e loura e Leite com café (MÁXIMO; DIDIER, 1990, p. 354-355).

Da morte de Noel floresceram muitas e muitas homenagens (MÁXIMO; DIDIER, 1990, p. 488-490). Algumas delas se valem de elementos de suas obras, como Inesquecivel Noel e A Vila emudeceu, compostas logo após sua morte, respectivamente por Osso e Cartola. Outras entrelaçam múltiplas referências, como Noel, rosa do samba, composta "Com uma rosa, uma rosa de versos dos sambas de Noel [...]", apenas por versos do sambista, "organizados” por Johny Alf e Paulo César Pinheiro (JUBRAN, 2000, p. 156). Ainda, outras composições contêm tintas de crítica e paródia: Caetano Veloso e Jorge Mautner formularam um feitiço muito diverso do Feitiço da Vila (Feitiço sem farofa). Os seguintes versos de Noel Rosa e Vadico: 
A Vila tem / Um feitiço sem farofa / Sem vela e sem vintém / Que nos faz bem... / Tendo nome de Princesa / Transformou o samba / Num feitiço decente / Que prende a gente [...]

Foram respondidos em Feitiço, de 2002:

Nosso samba / Tem feitiço, / Tem farofa / Tem vela e tem vintém / E tem também / Guitarra de rock 'n' roll, batuque de candomblé [...]

Em todos esses casos, o potencial criador de uma composição musical baseada em outras defronta-se com uma indagação complexa. A reprodução desautorizada de outra obra - melodia, letra, trecho - é plágio? ${ }^{19}$ Alguns "empréstimos" são admirados em Shakespeare, Elliot e Joyce (LANDES; POSNER, 2003a, p. 58-60). Atualmente, há balizas legais firmes às utilizações diretas de idéias, sendo permitidas sempre sua apropriação e transformação em novas obras intelectuais. Mas quais são os limites para a inspiração? Basta um critério mitigado de originalidade, considerada de forma fraca? ${ }^{20}$ Ou é preciso que sejam transfigurados, em alguma medida específica, os elementos da obra inspiradora? Como resolver conflitos de "aproximações" ou "cópias" não deliberadas?21

\title{
5. EXCEÇÕES AOS DiReitos AUTORAIS
}

\author{
"Nesse Brasil tão grande \\ Não se deve ser mesquinho \\ Quem ganha na avareza \\ Sempre perde no carinho.” \\ Samba da boa vontade, 1931, Noel Rosa e Carlos Alberto Ferreira Braga [João \\ de Barro].
}

O direito de reprodução de composições musicais, exclusividade do titular de direitos autorais, pode ser transferido a terceiros nos termos dos artigos 29, inciso I, e 49 da Lei 9.610/98. ${ }^{22}$ Contudo, em alguns casos, a reprodução é autorizada sem que seja necessária a autorização do titular. Permite o artigo 46 da referida lei:

$[\ldots]$

III - a citação em livros, jornais, revistas ou qualquer outro meio de comunicação, de passagens de qualquer obra, para fins de estudo, crítica ou polêmica, na medida justificada para o fim a atingir, indicando-se o nome do autor e a origem da obra;

$[\ldots]$ 
VIII - a reprodução, em quaisquer obras, de pequenos trechos de obras preexistentes, de qualquer natureza, ou de obra integral, quando de artes plásticas, sempre que a reprodução em si não seja o objetivo principal da obra nova e que não prejudique a exploração normal da obra reproduzida nem cause um prejuízo injustificado aos legítimos interesses dos autores.

O artigo 47 da mesma lei dispõe que: "São livres as paráfrases e paródias que não forem verdadeiras reproduções da obra originária nem lhe implicarem descrédito". ${ }^{23}$

Aparentemente, portanto, há razoável liberdade às criações musicais inspiradas em obras anteriores, que se valham de elementos destas como citação, como pequenos trechos ou como base para paródias. Tomando uma composição original como um quebra-cabeça, teríamos clareza quanto à utilização, por novas obras, de uma única peça, ou de uma figura similar, mas expressa de maneira diferente da primeira. Ou até mesmo da figura original, desde que distorcida com a finalidade de parodiar a primeira.

A criação de obras derivadas que fujam à paródia e às citações, contudo, carece de regras análogas. Dependeria sempre, à primeira vista, da autorização do titular de direitos autorais, tanto por conta da previsão do artigo 29 , incisos III e IV, da Lei 9.610/98 quanto pelo direito moral do autor de manter a integridade de suas criações. ${ }^{24}$ Assim, quem buscasse compor uma obra a partir das mesmas peças do primeiro quebra-cabeça, ainda que com um arranjo diferente, ou quem quisesse colorir ou envernizar a figura montada, enfrentaria fortes incertezas normativas.

Significa isto que a atual Lei de Direitos Autorais trata de reprodução de obras anteriores e da criação de obras derivadas sem precisar a extensão lícita das metamorfoses em uma ou mais obras intelectuais de que se parte, nem definir uma obrigação maleável de se fazer referência aos aproveitamentos anteriores. Conseqüentemente, a utilização de obras intelectuais, quer desautorizada, quer sem indicação do autor, traz inúmeros problemas específicos no campo musical, que poderiam ser resolvidos com maiores clareza quanto aos objetivos legais e flexibilidade para utilizações desautorizadas. ${ }^{25}$

No Brasil, a licitude das citações depende de sua finalidade ("estudo, crítica ou polêmica”) e da medida adequada. Muito mais restritiva para a criação de composições musicais é a exigência de indicar, sempre, "nome do autor e a origem da obra" citada. Esse requisito não foi previsto pela Convenção de Berna, que em seu artigo 10:1 prescreve apenas: "São lícitas as citações tiradas de uma obra já licitamente tornada acessível ao público, com a condição de que sejam conformes aos bons usos e na medida justificada pela finalidade a ser atingida”.

À legislação brasileira restritiva somam-se entendimentos de que "é preciso que a citação seja uma necessidade intelectual, imposta pela obra citante, que a reclama como elemento esclarecedor, auxiliar de sua própria compreensão" (MANSO, 1989a, 
p. 147). ${ }^{26}$ Discorda-se, porém, de que haja freios objetivos possíveis às citações, que consigam antecipadamente selecionar os usos legítimos. Também não seria razoável, pela dinâmica dos bens intelectuais, restringir a citação a determinados tipos de obras, como bem confirmaram os tribunais pátrios. ${ }^{27}$

Justificar a retomada de elementos de certas obras em novas criações, portanto, dificilmente ocorrerá com recurso à liberdade das citações. Pontes de Miranda (1983, p. 89) já reconhecia que "A introdução de medidas musicais em música de outrem, por chiste ou paródia, não é citação”. A alternativa das paródias, entendidas como obras derivadas ou como reproduções parciais permitidas, também conta com uma amarra relevante: a vedação de causarem descrédito à obra que parodiam (Ascensão, 1980, p. 19-20). Alguns autores chegam a estreitar ainda mais essa exceção aos direitos autorais, comprimindo-a entre a proteção à obra e também à honra do autor: "São livres, pois, as paráfrases, adaptações e outras transformações, nas condições que a lei prescreve e que, basicamente, referem-se ao respeito da obra originária, da sua integridade e da honra do autor, que não pode ser ridicularizado” (Cabral, 2003, p. 74-75).

Por diminuir custos de transação, a exclusividade às obras derivadas conferida ao titular de direitos autorais pode revelar-se eficiente, muito embora crie o risco de que não sejam produzidas obras intelectuais que desgostem esse titular (Abramowicz, 2005, p. 359). O inciso VIII do artigo 46 da Lei 9.610/98 permite a utilização de elementos de obras anteriores, sem diferenciar os casos de reprodução ou de nova obra derivada. A trôpega redação da Lei 5.988/73 (artigo 49, inciso I, alínea a) condicionava a possibilidade de uma obra intelectual incorporar partes de obras antigas ao "caráter científico, didático ou religioso", o que foi retificado pela nova lei (Carboni, 2003, p. 156-157), que exige apenas que "a reprodução em si não seja o objetivo principal da obra nova e que não prejudique a exploração normal da obra reproduzida nem cause um prejuízo injustificado aos legítimos interesses dos autores". 28

Os critérios de utilização de obras antigas reduzem as possibilidades criativas às hipóteses de "pequenos trechos" que não afetem “a exploração normal da obra reproduzida" ou os interesses de seus autores, desde que tal utilização não seja o objetivo da nova obra. No que tange às composições musicais, "Quando se trata de uma música com letra, por exemplo, a reprodução de um pequeno trecho de obra literária alheia, sem dúvida, não representa o objetivo principal da obra final" (Carboni, 2003, p. 158).

Pressupondo-se, no entanto, que os autores não possuem interesse justificável em simplesmente cercear a criação de obras intelectuais, permanece o indefinível obstáculo legal dos "pequenos trechos" - que admitem como único consenso não abrangerem toda a obra original. Daí a preocupação vocalizada por Frias (2006, p. 94): "parece-nos adequado que se estenda a imunidade da reprodução para uso privado às transformações e à tradução puramente privadas”. 
Em suma, as possibilidades relacionadas à criação de composições musicais com base em obras antigas têm parâmetros e amplitudes variáveis, sobrepondo-se em alguns casos, como visto na Tabela I:

TABela I: Liberdades para a criação de novas composições musicais

\begin{tabular}{|c|c|c|}
\hline PERMISSÃO & REQUISITOS & DISPOSITIVO DA LEI 9.610/98 \\
\hline $\begin{array}{r}\text { APROVEITAMENTO DE IDÉIAS, } \\
\text { SISTEMAS, MÉTODOS, PROJETOS, } \\
\text { ESQUEMAS, PLANOS OU REGRAS } \\
\text { PARA REALIZAR ATOS MENTAIS, } \\
\text { JOGOS OU NEGÓCIOS, } \\
\text { INFORMAÇÕES DE USO COMUM, } \\
\text { LEGENDAS, NOMES } \\
\text { E TÍTULOS ISOLADOS }\end{array}$ & & ARTIGO 8. ${ }^{\circ}$ \\
\hline $\begin{array}{r}\text { APROVEITAMENTO DE OBRAS } \\
\text { EM DOMÍNIO PÚBLICO }\end{array}$ & $\begin{array}{l}\text { - SETENTA ANOS DA MORTE DO AUTOR } \\
\text { - SETENTA ANOS DA PRIMEIRA } \\
\text { PUBLICAÇÃO (OBRAS ANÔNIMAS } \\
\text { OU PSEUDÔNIMAS) } \\
\text { - AUSÊNCIA DE SUCESSORES } \\
\text { DE AUTORES FALECIDOS } \\
\text { - AUTOR DESCONHECIDO }\end{array}$ & ARTIGOS 41, 43 E 45 \\
\hline CITAÇÃO DE PASSAGENS & $\begin{array}{l}\text { - PARA FINS DE ESTUDO, CRÍTICA } \\
\text { OU POLÊMICA } \\
\text { - NA MEDIDA JUSTIFICADA PARA } \\
\text { O FIM A ATINGIR } \\
\text { - INDICAÇÃO DO NOME DO AUTOR } \\
\text { E DA ORIGEM DA OBRA }\end{array}$ & ARTIGO 46, INCISO III \\
\hline $\begin{array}{r}\text { REPRODUÇÃO DE } \\
\text { PEQUENOS TRECHOS }\end{array}$ & $\begin{array}{l}\text { - A REPRODUCCÃO EM SI NÃO SER O } \\
\text { OBJETIVO PRINCIPAL DA OBRA NOVA } \\
\text { - NÃO PREJUDICAR A EXPLORACCÃO } \\
\text { NORMAL DA OBRA REPRODUZIDA } \\
\text { - NÃO CAUSAR PREJUÍZO } \\
\text { INJUSTIFICADO AOS LEGÍTIMOS } \\
\text { INTERESSES DOS AUTORES }\end{array}$ & ARTIGO 46, INCISO VIII \\
\hline PARÁFRASES E PARÓDIAS & $\begin{array}{l}\text { - NÃO SEREM VERDADEIRAS } \\
\text { REPRODUCCÕES DA OBRA ORIGINÁRIA } \\
\text { • NÃO IMPLICAREM DESCRÉDITO } \\
\dot{\grave{A}} \text { OBRA ORIGINÁRIA }\end{array}$ & ARTIGO 47 \\
\hline
\end{tabular}

Diretrizes legais mais objetivas selecionariam obras derivadas lícitas de ilícitas com base na competição entre a obra derivada ou reproduzida e a obra original: "Courts should not extend the derivative right to works that would not compete with plausible authorized transformations, nor should they extend the reproduction right to works that would not compete with the original” (Abramowicz, 2005, p. 388). Assim, seriam aceitos ele- 
mentos de outras obras apenas se não fosse visada a apropriação destas e de seus méritos econômicos. ${ }^{29}$

O atual escopo da proteção autoral, todavia, é insuficiente para determinadas utilizações socialmente aceitas e desejáveis de obras intelectuais. E sua estrutura normativa impõe uma limitação ulterior: as exceções dos artigos 46 e 47 meramente imunizam determinados agentes das sanções civis e penais aplicáveis às ofensas aos direitos autorais. Tais exceções não constituem expressamente direitos subjetivos, uma vez que a Lei 9.610/98 "não confere à coletividade direito oponível ao titular do direito" (FRIAS, 2006, p. 79-81). E a doutrina nacional descreve como exaustivas as exceções desta lei, ainda que estabelecidas "em razão de interesses da coletividade" (BITTAR, 2005, p. 59). ${ }^{30}$

Esses mesmos interesses da coletividade, como se percebe das composições musicais implicadas na obra de Noel Rosa, impõem outro tratamento para os direitos autorais, reclamando em muitos casos balizas rígidas ao exercício desses direitos. Em outros casos, a desnecessidade de negociação com seu titular, ainda que alguma remuneração seja prevista, permitiria o melhor aproveitamento social de determinadas obras intelectuais. ${ }^{31}$ Por esse motivo abundam as propostas de licenciamento compulsório relacionadas a bens intelectuais, ${ }^{32}$ incluindo o tabelamento de preços para uso de determinadas obras (Bittar, 2005, p. 67-68), o que reduz os custos de transação necessários para sua exploração, ou permissão plena e não remunerada de uso a obras intelectuais "fora de catálogo" (Lessig, 2004, p. 299-300).

\section{DOMÍNIO PÚBLICO?}

"Não te vejo e nem te escuto,

O meu samba está de luto.”

Silêncio de um minuto, 1935, Noel Rosa.

Em 2008, a obra intelectual de Noel Rosa cairá em domínio público. Suas obras que não tenham co-autores terão os direitos autorais patrimoniais exauridos. Melodias e letras poderão ser utilizadas com maior flexibilidade por quaisquer interessados, quer para a produção de obras derivadas, ${ }^{33}$ quer para outros fins. ${ }^{34}$

Após o esgotamento dos direitos autorais sobre as composições musicais do sambista, caberá ao Estado sua proteção, porque pertencentes a toda a sociedade (Pontes de Miranda, 1983, p. 94-95). Alguns autores consideram que a obra caída em domínio público "faz parte da identidade cultural de um povo. Mantê-la intacta é um dever do Estado" (Cabral, 2003, p. 46). O autor original seria indiretamente tutelado, não recaindo a atenção estatal apenas sobre suas obras: "Observa-se, pois, ante a posição do Estado, de um lado, verdadeiro direito-dever, na defesa da obra, exatamente para 
proteção de valores da cultura do País e, de outro, caso particular de exercício de direitos morais, por quem não detém a titularidade da criação” (Bittar, 2005, p. 55-56).

Essas construções, além de priorizarem um hipotético - e pouco provável domínio público "nacional", sugerem que se resguardem os bens intelectuais "intactos", o que contraria a própria natureza das "criações do espírito", sempre dependentes de diálogos e de fontes. Uma repetição de El ingenioso hidalgo Don Quixote de la Mancha nunca diminuirá Cervantes, mesmo que se confunda com sua obra (BORGES, 1998), ou que dê origem a paráfrases, transcriações ou "traduções" de tempo e lugar, mas não idiomáticas (FRANCO, 2003).

A temporariedade, princípio comum a diversas variedades de propriedade intelectual, tem como fundamento o retorno à sociedade de tudo o que o autor dela extraiu para criar sua obra, imersa em seu meio e em sua história. Garante-se por determinado tempo a exclusividade ao autor no uso e gozo da obra criada; depois, com a queda em domínio público, ela pode ser repartida e aproveitada por toda a sociedade. ${ }^{35}$

Por isso mesmo, na escolha política do prazo de proteção autoral, faz pouco sentido inserir uma extensão à duração dos direitos sobre obras já criadas, como prevista no artigo 112 da Lei 9.610/98. ${ }^{36}$ Se os incentivos da legislação anterior haviam sido suficientes para a criação da obra, por que se renunciou a dez anos de domínio público? Essa escolha legislativa, alvo de exíguas manifestações no Brasil, sofreu fortes críticas no exterior. ${ }^{37}$

Para o melhor aproveitamento das obras caídas em domínio público, sua gratuidade é fundamental - aliando autorização jurídica e liberdade de uso a acesso facilitado (SAMUELSON, 2006, p. 820-823). Felizmente, os regimes especiais de utilização, com remuneração ao Estado, foram eliminados no Brasil (BITTAR, 2005, p. 112-113). Os custos de oportunidade representam, portanto, o cerne das considerações de quem se volta ao domínio público com interesses não-criativos, e são excluídos do cálculo de risco daqueles interessados eminentemente no processo intelectual criativo - que ganham mais à proporção que aumentam as obras desprotegidas por direitos autorais.

Landes e Posner (2003b) propuseram direitos autorais renováveis indefinidamente, exatamente por contestarem a eficiência econômica da entrada de obras intelectuais em domínio público. Os exemplos dos autores para comprovar essa hipótese, além das obras “órfãs” por conta do desestímulo advindo de sua utilização ser não-exclusiva, são reproduções da Mona Lisa e de quadros de Vincent van Gogh, que teriam desgastado o poder de atração dos originais. Respostas técnico-econômicas contrapõem-se à conclusão dos autores, apoiadas pela simples constatação de que são precisamente essas obras as que sobrevivem com maior brilho (KARJALA, 2006).

$\mathrm{O}$ "equilíbrio entre os direitos patrimoniais do autor e o interesse da sociedade é, sem dúvida, uma construção jurídica notável e que tem seu ponto básico na temporalidade dos direitos autorais" (Cabral, 2003:66). Com a devida formulação legal, 
será possível no futuro escutar obras como White Rabbit, de 1967, composta pela banda Jefferson Airplane apenas sobre referências à obra de Charles Lutwidge Dodgson. ${ }^{38}$ E os personagens dos Sonhos de Akira Kurosawa poderão caminhar despreocupadamente sobre as pinturas de Van Gogh.

\section{Conclusão}

"Adeus é pra quem deixa a vida

É sempre na certa em que eu jogo

Três palavras vou gritar por despedida:

'Até amanhã! Até já! Até logo!'.”

Até amanhã, 1932, Noel Rosa.

"Eu quisera esquecer o passado,

Eu quisera, mas sou obrigado,

A lembrar o grande Noel.

Ainda resta a cadeira vazia

Da escola de filosofia

No bairro de Vila Isabel."

Cadeira vazia, Angenor de Oliveira [Cartola], Nuno Veloso.

Com a profissionalização de músicos e intérpretes e o crescimento da indústria fonográfica e do rádio, regras eficientes e justas para as composições musicais foram cada vez mais reclamadas - tanto pela classe artística quanto pelas empresas que se valiam de suas criações. A "passagem da gratuidade artística (quando o povo urbano correspondia apenas às suas expectativas, produzindo para si) para a nova fase de produção destinada à venda (em que o compositor passava a usar a cultura de sua classe como matéria-prima na produção artística dirigida a outros)” (Tinhorão, 1998, p. 277-278) modificou a maneira de enxergar o samba. Essa nova perspectiva foi acompanhada de mudanças relacionadas à noção de autoria e à liberdade para o aproveitamento de obras intelectuais sem autorização de seus titulares.

A informalidade nas relações jurídicas entre autores e titulares de direitos autorais (que nem sempre chegavam a coincidir), contudo, prevaleceu por muito tempo desde os anos 1930 e a explosão do samba. A formalização irregular da exploração das composições musicais perdurou como regra, em oposição ao reconhecimento da paternidade sobre elas e a sua utilização sob marcos legais precisos. Resultados dessas práticas são a impressionante variação de formas e valores de remuneração de autores musicais e uma acentuada assunção de riscos por autores de obras derivadas, ou de obras que contenham elementos de criações anteriores. 
As incertezas decorrentes das atuais permissões legais ao aproveitamento de obras já criadas, idêntica tanto para composições musicais quanto para as demais (Pontes de Miranda, 1983, p. 126-129), aumentam os custos relacionados à criação musical. Análises jurídicas, controle de acervos, batalhas judiciais e registros de partituras e letras afastam músicos e intérpretes de sua atividade-fim. A profissionalização das escolas de samba (Vianna, 2004, p. 180), pasteurizando alguns processos criativos, é concomitante ao desprestígio dos sambistas amadores. ${ }^{39}$ A Lei 9.610/98 se por um lado protege o verdadeiro autor, por outro impõe fardos pesados à criação musical. Descompassados, os incentivos legais perdem cadência. Geram mais ruídos do que sintonias.

A utilização da música popular por Getúlio Vargas, como expressão do nacionalismo do Estado Novo (Tinhorão, 1998, p. 289-304), relegou seus autores ao segundo plano. O sucesso da Bossa Nova, "bem ao gosto do otimismo reinante nos anos JK" (Vianna, 2004, p. 176), reforçou a autoria individualizada, que prevaleceu nos desenhos normativos posteriores. No entanto, músicas coletivas sem organização, assim como as diretamente calcadas sobre outras anteriores, carecem de mecanismos adequados.

"A fundamental task of copyright law viewed economically [...] [is to] strike the optimal balance between the effect of copyright protection in encouraging the creation of new works by reducing copying and its effect in discouraging the creation of new works by raising the costs of creating them" (LANDES; POSNER: 2003a, p. 69). Para que o samba não se ressinta dessas leis, alguma afinação certamente é necessária.

: ARTIGO APROVADO (12/09/2007) : RECEBIDO EM 18/03/2007

NOTAS

1 Lemley (2005, p. 1058-1059) enquadra em cinco categorias os custos resultantes de direitos de propriedade intelectual excessivos: "First, intellectual property rights distort markets away from the competitive norm, and therefore create static inefficiencies in the form of deadweight losses. Second, intellectual property rights interfere with the ability of other creators to work, and therefore create dynamic inefficiencies. Third, the prospect of intellectual property rights encourages rent-seeking behavior that is socially wasteful. Forth, enforcement of intellectual property rights imposes administrative costs. Finally, overinvestment in research and development is itself distortionary" (grifos nossos).

2 A argumentação híbrida, comum na doutrina nacional sobre os direitos autorais, pode ser verificada em Ascensão (1980, p. 334-337), Bittar (2005, p. 10-11), Cabral (2003, p. 48-49), (Cerqueira, 1946, p. 67-70), Manso (1989a, p. 143) e Silveira (2005, p. 12-4). Carboni (2003, p. 62-63), embora afaste os direitos morais do autor da "mera proteção individualista do sujeito-autor", não os insere no conjunto de medidas de política pública voltadas ao desenvolvimento das artes, 
mas os identifica como expressão do "interesse social no reconhecimento da identidade do emissor da mensagem". Landes e Posner (2003a, p. 63-66) notam a penetração, nos países de common law, do conceito de "personality", base para direitos autorais morais. Para os autores, a valorização do indivíduo criador estaria atrelada à ascensão das teorias românticas sobre criatividade, tida como expressão da personalidade.

3 Nos termos deste autor, “a propriedade não é uma coisa que existe fora das regras que a constituem”.

4 É imperativo, em discussões mais abrangentes sobre os efeitos das normas de direitos autorais, que sejam examinadas suas conexões com a pluralidade de discursos e a garantia de manifestação das minorias, em especial no contexto da formulação de políticas submetidas ao regime democrático e influentes sobre a liberdade de expressão (vide TEHRANIAN, 2005). Essa análise foge ao escopo do presente artigo, que se restringe a apontar a falácia na associação de órgãos de censura à "defesa dos interesses dos titulares" de direitos autorais (BITTAR, 2005, p. 128-129), impossível na medida em que os potenciais titulares desses direitos são todos os cidadãos (inclusive os interessados na criação e na difusão de obras “subversivas").

5 Convenção de Berna relativa à Proteção das Obras Literárias e Artísticas, promulgada no Brasil pelo Decreto 75.699, de 06.05.1975 (como revista na Ata de Paris, de 24.07.1971), hoje sob o manto da Organização Mundial da Propriedade Intelectual, órgão da Organização das Nações Unidas.

6 Constituição da República Federativa do Brasil de 1988, artigo 5. ${ }^{\circ}$ XXVII: "aos autores pertence o direito exclusivo de utilização, publicação ou reprodução de suas obras, transmissível aos herdeiros pelo tempo que a lei fixar”.

7 Acordo Trade Related Aspects of Intellectual Property Rights, Anexo 1C da Ata Final que Incorpora os Resultados da Rodada Uruguai de Negociações Comerciais Multilaterais do GATT (criando a Organização Mundial de Comércio), assinada em Marraqueche, Marrocos, em 12.04.1994, e promulgado no Brasil pelo Decreto 1.355, de 30.12.1994.

8 Vide Lei 9.610/98, artigo 7. : "São obras intelectuais protegidas as criações do espírito, expressas por qualquer meio ou fixadas em qualquer suporte, tangível ou intangível, conhecido ou que se invente no futuro”.

9 A jurisprudência brasileira corrobora este entendimento, como exemplificou notória disputa sobre a hipotética proteção autoral ao "esquema geral" do programa televisivo Big Brother Brasil, em oposição ao concorrente Casa dos Artistas (Agravo Regimental 225.882.4/1-01, 5. ${ }^{a}$ Câmara de Direito Privado do Tribunal de Justiça de São Paulo. Agravantes: TV Globo e Endemol Entertainment International B.V., recorrida:TVSBT Canal 4 de São Paulo S.A. Relator Ministro Marcus Vinicius dos Santos Andrade. Acórdão proferido em 08.11.2001). Em recente decisão, o Superior Tribunal de Justiça confirmou essa orientação (Recurso Especial 661.022/RJ, 3. ${ }^{a}$ Turma do STJ. Recorrente: Mostaert Publicidade e Promoções Ltda., recorrido: Banco Bradesco S.A. Relator Ministro Castro Filho. Acórdão proferido em 12.09.2006).

10 Arewa (2006, p. 603-604) lista interpolações e “empréstimos” realizados por Bach, assim como por outros autores a partir de suas obras. Ascensão (1980:13) assevera que o plágio "só surge quando a própria estruturação ou apresentação do tema é aproveitada”.

11 Máximo e Didier (1990, p. 255-256) detalham as reclamações de Donga, que tinham por objeto a canção Fita amarela, relembrando inúmeras composições anteriores tanto a Noel quanto a Donga que já apresentavam os temas poético e melódico presentes na música. Para Carboni (2003:201), a questão da diluição da autoria torna-se mais sensível nos dias atuais: "Com o surgimento da multimídia e das redes de informação, a concepção extremamente individualista do direito moral de autor pode se tornar um perigoso obstáculo à criatividade, acarretando a inviabilização de projetos, por questões de mero capricho pessoal, camufladas sob o discurso da defesa desse direito. Defendemos, assim, um deslocamento do direito moral de autor do campo individualista do direito natural à obra intelectual para o campo funcional da identificação do criador, visando ao interesse social no reconhecimento da sua identidade enquanto emissor de uma mensagem”.

12 Máximo e Didier (1990, p. 190) indagam “de quanta gente ele tem comprado parceria, colocando seu nome nos selos dos discos, nas partituras, em toda parte? E às vezes só o seu nome, condenando o verdadeiro autor ao anonimato. Faz isso com tanta freqüência que se pergunta por aí se serão mesmo suas canções tão bonitas como Lua Nova e $A$ Voz do Violão". "Podemos ser compreensivos e observar que as atitudes do cantor não eram chocantes no contexto da época. Também podemos ser muito duros e simplesmente sublinhar a tibieza de caráter de Chico. Mas parece mais interessante reparar que ele cumpriu uma função tutelar típica das relações entre elite, e camadas populares na República Velha. 
Branco, famoso, com estudo, ele levou o chamado "samba do morro" para a "cidade" sem retirar os compositores de uma posição socialmente precária e subalterna - de prestadores de serviços pagos com uma pequena fatia do bolo” (Vianna, 2004:47).

13 Não quero mais, de Angenor de Oliveira [Cartola] e Carlos Cachaça, foi registrado em 1935 como de Carlos e Zé com Fome (VIANNA, 2004, p. 58). Arrasta a sandália, sucesso do carnaval de 1933, foi rapinada de seu autor por Baiaco e Aurélio Gomes por meio de violentas ameaças (MÁXIMO; DIDIER, 1990, p. 290-291). Lataria, de 1930, foi creditada a Carlos Alberto Ferreira Braga [João de Barro] e Henrique Foréis Domingues [Almirante]; a co-autoria de Noel Rosa, porém, foi diversas vezes admitida por João de Barro (MÁXIMO; DIDIER, 1990, p. 129-130).

14 O próprio Noel Rosa, ao auxiliar músicos menos talentosos, mais de uma vez propôs "Uma letra por uma cerveja!” (Máximo, Didier, 1990:74). Vianna (2004) aponta que vendiam sambas por necessidade Wilson Batista e Ataulfo Alves. Máximo e Didier (1990) incluem também Cartola e Gradim, ressalvando que Cartola, ao contrário de tantos outros, negociara com Francisco Alves ceder apenas direitos de execução, e nunca os créditos por suas músicas. Os autores, ao tratarem da criação de $O$ orvalho vem caindo por Noel e o ex-boxeador Giuseppe Gelsomino [Kid Pepe], insinuam que "na criação deste esplêndido samba, Noel entrou com música e letra. Kid Pepe, com os músculos” (p. 273).

15 Máximo e Didier (1990, p. 193-194) anotam que Noel, após aproximação inicial com o cantor, aceitou um carro em troca dos direitos autorais sobre alguns dos sambas que fosse compondo.

16 A glorificação do trabalho desejada pelo Estado Novo mais tarde seduziria Wilson Batista, antes exaltador da malandragem (VIANNA, 2004, p. 105). O próprio Noel Rosa, por sua vez, tem uma série de composições elogiosas à vadiagem do malandro, como Cadê trabalho?, de 1931 (MÁXIMO; DIDIER, 1990, p. 196-197).

17 Desde jovem, Noel se entregava a "um de seus prazeres maiores: parodiar o Hino Nacional [...] solando a melodia de Francisco Manuel da Silva em ritmo de valsa, tango, maxixe, ou arranjando para ela letras que fariam Osório Duque Estrada tremer no túmulo" (MÁXIMO; DIDIER, 1990, p. 84).

18 A utilização de trechos das próprias letras ou melodias para compor novas obras musicais é comum também no rock, como se percebe nas composições Glass Onion, dos Beatles, ou Destroyer, dos Kinks, que retomam inúmeras composições das respectivos bandas.

19 Burke (2001) relata mudanças históricas no conceito de plágio, sempre, porém, associado à apropriação desautorizada: "Na Roma Antiga, alguém que roubasse um escravo era conhecido como 'plagiarius', mas o poeta Marcial aplicou o termo aos escritores que imitavam seu trabalho [...] Em Atenas, Eurípides e Platão foram acusados de roubar as idéias de outros autores e filósofos. No Renascimento, os dramaturgos eram às vezes acusados de plágio, incluindo Shakespeare, porque as tramas de 'Hamlet' e 'Romeu e Julieta', por exemplo, foram tiradas de autores mais antigos. No mundo da ciência, já extremamente competitivo no final do século 17, os seguidores de Isaac Newton afirmaram que Leibniz plagiou a descoberta do cálculo de Newton, enquanto um colega inglês acusou o próprio Newton de plágio". Landes e Posner (2003a, p. 62) reconhecem "the absence from the law of any general principle that appropriating intellectual property created by another person is wrongful, although particular forms of misappropriation are sometimes forbidden".

20 A doutrina brasileira descreve uma "originalidade de caráter relativo", como nas formulações de alguns de seus expoentes: "apresenta a originalidade caráter relativo, não se exigindo, pois, novidade absoluta, eis que inexorável é, de um ou outro modo, o aproveitamento, até inconsciente, do acervo cultural comum" (BITTAR, 2005, p. 23); "Essa originalidade deve ter caráter relativo, uma vez que é inevitável o aproveitamento, até inconsciente, do acervo cultural comum" (CARBONI, 2003, p. 55). Jorge Luis Borges explicou com maestria tais semelhanças: "Creo que una forma de felicidad es la lectura; otra forma de felicidad menor es la creación poética, o lo que llamamos creación, que es una mezcla de olvido y recuerdo de lo que hemos leído".

21 As cortes estadunidenses abordaram a apropriação inconsciente de direitos autorais ao julgar a utilização da melodia de He's So Fine - composta por Ronald Mack e gravada em 1962 pela banda Chiffons - por George Harrison na música My Sweet Lord, de 1969. "Did Harrison deliberately use the music of He's So Fine? I do not believe he did so deliberately. Nevertheless, it is clear that My Sweet Lord is the very same song as He's So Fine with different words, and Harrison had access to He's So Fine. This is, under the law, infringement of copyright, and is no less so even though subconsciously accomplished." (Bright Tunes Music Corp. v. Harrisongs Music, Ltd., 420 F.Supp. 177 (S.D.N.Y., 1976).) Além de dividir os rendi-

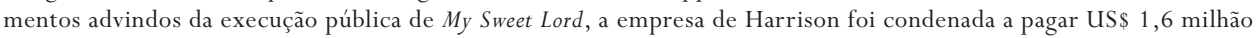
(SELF, 1993). 
22 Noel Rosa, por exemplo, vendeu os direitos de Com que roupa? antes de o samba começar a ser vendido em disco, recebendo quantia irrisória por uma das composições mais tocadas na história do carnaval carioca. Mais tarde, cederia também os direitos de Mão no remo, composta em parceria com Ary Barroso, por 50 mil réis (MÁXIMO; DIDIER, 1990, p. 156,181).

23 Os tribunais brasileiros confirmam a licitude das paródias, não havendo descrédito à criação originária - vide Agravo de Instrumento 2000.002.09901 1 1. ${ }^{\text {a }}$ Câmara Cível do Tribunal de Justiça do Estado do Rio de Janeiro. Agravante: Partido Democrático Trabalhista e agravado Carillo \& Pastore Euro RECG Comunicações Ltda. Relatora Des. Maria Augusta Vaz M. de Figueiredo. Acórdão registrado em 02.05.2001. Discussão utilitarista sobre a regulamentação das paródias é aprofundada por Landes e Posner (2003a, p. 147-159).

24 "São direitos morais do autor: o de assegurar a integridade da obra, opondo-se a quaisquer modificações ou à prática de atos que, de qualquer forma, possam prejudicá-la ou atingi-lo, como autor, em sua reputação ou honra" - artigo 24, inciso IV, da Lei 9.610/98.

25 Uma proposta nesse sentido parte da diferenciação entre reprodução e criação de obras derivadas - a exclusividade sobre obras derivadas não estimularia de modo relevante a criação de novas obras, mas impediria que obras redundantes, e portanto ineficientes, proliferassem (Abramowicz, 2005:329-332). Portanto, seria preciso dosar com cuidado as permissões a obras derivadas sem autorização do titular de direitos autorais e conferir permissão legal apenas àquelas que não concorressem com a obra original ou suas derivações.

26 É gritante o descabimento do requisito de "necessidade intelectual” desenvolvido por Manso (1989a, p. 150): “O autor que pretende expor um ponto de vista, ainda que não seja em si mesmo controvertido, tem necessidade de demonstrar que tal modo de pensar não é incomum, que não é isolado e que outros, antes dele, assim também pensaram. Logo, terá toda liberdade de citar trechos desses autores, na medida em que esses trechos sejam suficientes para comprovar o mesmo ponto de vista. Sem o confronto de dois pensamentos, é impossível falar em citações. Assim, sem necessidade intelectual (científica, técnica, artística ou de outra ordem cultural), não se justificam as citações, mesmo que estas se façam nos limites dos bons costumes, porque a citação é o instrumento de saber e de debates". Restritiva e instrumental, esta visão das citações as submete ao imponderável jugo da "necessidade intelectual", inapta a mensurar ou sequer indicar as finalidades estéticas às quais as obras intelectuais se orientariam. Visto o interesse desta citação em particular, de "confronto de pensamentos”, lamenta-se a concessão metalingüística ao entendimento questionado.

27 Confirma essa possibilidade o Recurso Extraordinário 113.505-1, 1. a Turma do Supremo Tribunal Federal. Recorrente: TV Globo Ltda, recorrido: TV Studios Rio de Janeiro Ltda. Relator Ministro Moreira Alves. Acórdão proferido em 28.02.1989 (decisão exarada na vigência da antiga Lei 5.988/73). Ver também Ascensão (1980, p. 259-260).

28 São retomados literalmente os critérios da Convenção de Berna, que dispõe em seu artigo 9.2: "às legislações dos países da União reserva-se a faculdade de permitir a reprodução das referidas obras em certos casos especiais, contanto que tal reprodução não afete a exploração normal da obra nem cause prejuízo injustificado aos interesses legítimos do autor”. O Acordo TRIPs reitera essas condições em seu artigo 13: “Os Membros restringirão a limitação ou exceções aos direitos exclusivos a determinados casos especiais, que não conflitem com a exploração normal da obra e não prejudiquem injustificavelmente os interesses legítimos do titular do direito".

29 Este parâmetro é corroborado pela jurisprudência; vide decisão que utiliza o termo "parasitismo" para ilustrar a conduta do réu que se apropriara de obra alheia com o fim de promover seus produtos: $16 .{ }^{a}$ Câmara Cível. Tribunal de Justiça do Estado do Rio de Janeiro. Apelação Cível 2006.001.08169. Apelantes: Bruno Villela Barreto Borges, K2 Comércio de Confecções Ltda. e Outros, apelada: os mesmos. Relator Des. Ronald Valladares. Acórdão registrado em 20.06.2006.

30 A exaustividade da previsão, na Lei 9.610/98, de exceções aos direitos autorais é ecoada por Cabral (2003, p. 70) e Silveira (2005, p. 59-60), entre outros.

31 Para Landes e Posner (2003a, p. 421), "the higher transaction costs are, the less likely the law is to seek to regulate transactions, since a property right being a right against the world - that is, a right to insist that anyone wanting it negotiate with the owner of it - can be reallocated from lower to higher valued users only through voluntary transactions. If such transactions are infeasible because of high transaction costs, the law will narrow the property right. That is why we expect (and find) a much broader fair use doctrine (which in effect permits an uncompensated taking of property) in intellectual property law than in the law of physical property". 
32 Manso (1989b, p. 175), ao tratar da previsão constitucional da exclusividade, defende que apenas o titular dos direitos autorais poderia negociar a remuneração pelo exercício desses direitos. Essa interpretação restritiva, porém, segundo a qual "A Constituição deferiu ao legislador ordinário competência apenas para limitar a duração no tempo do direito autoral”, distancia-se da visão de um sistema de direitos autorais como mecanismo de estímulo à criação e à difusão dos bens intelectuais.

33 "O problema da obra caída em domínio público é delicado. Elas não se tornam coisa pública, res derelicta. Ninguém pode delas apossar-se. O Estado tem a incumbência constitucional de protegê-las e garantir sua integridade. Mas, de outra parte, quando o legislador diz que quem adapta obra caída em domínio público tem direitos autorais sobre o trabalho que efetuou, está admitindo, obviamente, que a obra seja retrabalhada, o que a lei permite claramente" (Cabral, 2003, p. 38).

34 O uso de obras intelectuais em domínio público para a criação de novas obras raramente é discutido pelos tribunais. Por outro lado, a entrada de bens intelectuais em domínio público costuma ser apreciada em juízo. Vide (a) Apelação Cível 2003.001.12434, 5. ${ }^{\text {a }}$ Câmara Cível do Tribunal de Justiça do Rio de Janeiro. Apelante: Alberto Hekel Tavares e Zaira Carvajal Tavares Cuervello, apelada, Raimundo Fagner Candido Lopes e Roberto Hekel Tavares, apelados: os mesmos. Relator Desembargador Milton Fernandes de Souza. Acórdão proferido em 02.07.2003; (b) Recurso Especial

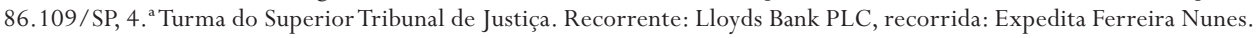
Relator Ministro Barros Monteiro. Acórdão proferido em 28.06.2001; e (c) Apelação Cível 418.016-1, 8. ${ }^{a}$ Câmara Cível do Tribunal de Alçada do Estado de Minas Gerais. Apelante: Talento Jóias Ltda., apelada: Renata Hermeto Sá Motta. Relator Sebastião Pereira de Souza. Acórdão proferido em 12.12.2003.

35 O artigo 27 da Declaração Universal dos Direitos do Homem, de 1948, prescreve: "1. Todo homem tem o direito de participar livremente da vida cultural da comunidade, de fruir as artes e de participar do progresso científico e de seus benefícios. 2. Todo homem tem direito à proteção dos interesses morais e materiais decorrentes de qualquer produção científica, literária ou artística da qual seja autor”. Ascensão (1980:190) é certeiro ao adjetivar propostas de direitos autorais perpétuos: "Trata-se de um absurdo, pois a proteção do autor não exige o sacrifício permanente do interesse público".

36 Prescreve o artigo 112 da Lei n. 9.610/98: "Se uma obra, em conseqüência de ter expirado o prazo de proteção que lhe era anteriormente reconhecido pelo $\S 2 .^{\circ}$ do art. 42 da Lei n. 5.988, de 14 de dezembro de 1973, caiu no domínio público, não terá o prazo de proteção dos direitos patrimoniais ampliado por força do art. 41 desta Lei”. Contrario sensu, se ainda não houvesse expirado seu prazo de proteção, permaneceriam vigentes os direitos autorais patrimoniais por mais do que os sessenta anos estabelecidos pela Lei 5.988/73.

37 Nos Estados Unidos, a constitucionalidade da extensão dos direitos autorais pelo Sonny Bono Copyright Term Extension Act foi questionada no caso Eldred $v$. Ashcroft, descrito em detalhes por Lessig (2004). Landes e Posner (2003a, p. 409), ao defender que mudanças legislativas tenham sempre efeito prospectivo, denunciam que "The possibility of retroactive legislation is a candle to rent-seeking moths".

38 Poderíamos escutar esse sucesso, criado a partir de elementos outrora protegidos por direitos autorais, mesmo se isso houvesse ocorrido sob as leis atuais, com direitos autorais mais duradouros, visto que na época de sua criação já haviam transcorrido setenta anos da morte do autor (1898). Note-se que, embora suas obras-primas Alice's Adventures in Wonderland, de 1864 (cujo título original é Alice's Adventures Under Ground), e Through the Looking-Glass andWhat Alice Found There, de 1871, tenham sido escritas sob o pseudônimo Lewis Carroll (Carroll, 2004), o autor foi conhecido antes de se passarem setenta anos de sua publicação (vide Lei 9.610/98, artigo 43, parágrafo único).

39 Vianna (2004, p. 69) lembra que Walt Disney levou para os Estados Unidos "o sambista/malandro brasileiro encarnado em Zé Carioca, cujo perfil há quem considere muito parecido com o de Paulo da Portela. Se foi essa a inspiração, Disney nunca pagou direitos de imagem”.

\section{REFERÊNCIAS BIBLIOGRÁFICAS}

ABRAMOWICZ, Michael. A theory of copyright's derivative rights and related doctrines. Minnesota Law Review, Minneapolis, v. 90, n. 2, p. 318-388, dez. 2005. 
AKIRA Kurosawa's dreams: sonhos de Akira Kurosawa. Direção: Akira Kurosawa. Produção: Hisao Kurosawa; Mike Y. Inoue. Los Angeles: Warner Brothers, 1990. 1 DVD (120min), widescreen, color. Produzido por Warner Video Home.

AREWA, Olufunmilayo. From J.C. Bach to hip hop: musical borrowing, copyright and cultural context. North Carolina Law Review, Chapel Hill, v. 84, n. 2, p. 547-645, fev. 2006.

ASCARELLI, Tullio. Teoria della concorrenza e dei beni immateriali (1957). Tradução espanhola de E. Verdera e L. Suárez-Llanos. Teoría de la concurrencia y de los bienes inmateriales. Barcelona: Bosch Casa Editorial, 1970.

ASCENSÃO, José de Oliveira. Direito autoral. Rio de Janeiro: Forense, 1980.

BARBOSA, Denis Borges. Uma introdução à propriedade intelectual. 2. ed. Rio de Janeiro: Lumen Juris, 2003. BITTAR, Carlos Alberto. Direito de autor. 4. ed. Rio de Janeiro: Forense Universitária, 2005.

BORGES, Jorge Luis. Pierre Menard, autor del Quijote. Ficciones (1944). Tradução portuguesa de Carlos Nejar. Pierre Menard, autor do Quixote (Ficções). Obras completas de Jorge Luis Borges. São Paulo: Globo, 1998. v. 1. p. 490-498.

BURKE, Peter. A propriedade das idéias. Folha de S. Paulo, São Paulo, 24 jun. 2001, MAIS!.

CABRAL, Plínio. A nova lei de direitos autorais: comentários. 4. ed. São Paulo: Harbra, 2003.

CALVINO, Italo. Se una notte d'inverno un viaggiatore (1979). Tradução italiana de N. Moulin. Se um viajante numa noite de inverno. São Paulo: Companhia das Letras, 1990.

CARBONI, Guilherme C. O direito de autor na multimídia. São Paulo: Quartier Latin, 2003.

CARROLL, Lewis. Alice's Adventures in Wonderland and Through the Looking-Glass and What Alice Found There. Nova York: Barnes \& Noble, 2004.

CERQUEIRA, João da Gama. Tratado da propriedade intelectual. Parte I. Rio de Janeiro: Forense, 1946.

DANTAS, André. Malandro que é malandro.... Morpheus - Revista Eletrônica em Ciências Humanas, Rio de Janeiro, ano 2, n. 3, ISSN 1676, 2003. Disponível em:

<http://www.unirio.br/morpheusonline/Número\%2003\%20-\%20especial\%20memória/andrédantas.htm>. Acesso em: 11 jan. 2007.

FRANCO, Jefferson Luiz. Fernando Sabino: tradutor de Dom Casmurro. Revista Letras, Curitiba, n. 61, especial, p. 367-375, 2003. Disponível em:

<http://calvados.c3sl.ufpr.br/ojs2/index.php/letras/article/viewFile/2898/2380>. Acesso em: 28 fev. 2007. FRIAS, Felipe Barreto. O instituto da cópia privada no direito autoral brasileiro - análise dogmática e crítica. Revista dos Tribunais, São Paulo, ano 95, v. 846, p. 66-96, abr. 2006.

JUBRAN, Omar. Noel pela primeira vez (encarte). São Paulo: Funarte/Velas, 2000.

KARJALA, Dennis. Congestion Externalities and Extended Copyright Protection. Georgetown Law Journal, Washington, v. n. 94, n. 4, p. 1065-86, abr. 2006.

LANDES, William; POSNER, Richard. The economic structure of intellectual property rights. Cambridge/Londres: Harvard University Press, 2003a.

$518,2003 b$

LEMLEY, Mark. Property, intellectual property and free riding. Texas Law Review, Austin, v. 85, n. 4, p. 1031 -

1075, mar. 2005.

LESSIG, Lawrence. Free culture: how big media uses technology and the law to lock down culture and control creativity. Nova York: Penguin, 2004. Disponível em: <http://www.free-culture.cc/freeculture.pdf $>$. Acesso em: 15 fev. 2007.

LOCKE, John. Two Treatises of Government: The True Original, Extent and End of Civil-Government (1689)

Tradução inglesa de M. Lopes e, M.L. Costa. Segundo Tratado sobre o Governo Civil: ensaio sobre a origem, os limites e os fins verdadeiros do governo civil. Petrópolis: Vozes, 1994.

LOPES, José Reinaldo de Lima. O direito na história: lições introdutórias. São Paulo: Max Limonad, 2000.

LOPES, Nei. Sambeabá: o samba que não se aprende na escola. Rio de janeiro: Casa da Palavra/Folha Seca, 2003. MANSO, Eduardo J. Vieira. Parecer: Obra inédita: conceito - divulgação de obra inédita - citação: conceitos direitos violados; sanções aplicáveis. Revista de Direito Civil, Imobiliário, Agrário e Empresarial, São Paulo, ano 13, n. 50, p. 133-162, out.-dez. 1989a.

- Comentários de jurisprudência: direito autoral. Revista de Direito Civil, Imobiliário, Agrário e Empresarial, São Paulo, ano 13, n. 47, p. 171-177, jan.-mar. 1989b.

MÁXIMO, João; DIDIER, Carlos. Noel Rosa: uma bio grafia. Brasília: Universidade de Brasília, 1990.

NOEL ROSA. Noel pela primeira vez. Organização de Omar Jubran. São Paulo: Funarte/Velas, 2000. 7 v., 14 CD, remasterizado em digital.

PONTES DE MIRANDA, Francisco Cavalcanti. Tratado de direito privado. 4. ed. São Paulo: RT, 1983. v. 16. SAMUELSON, Pamela. Enriching discourse on public domains. Duke Law Journal, Durham, v. 55, n. 4, p. 783. 834 , fev. 2006. 
SELF, J. The "My Sweet Lord"/"He’s So Fine” plagiarism suit. The 910, 1993. Disponível em: <http://abbeyrd.best.vwh.net/mysweet.htm>. Acesso em: 11 jan. 2007.

SILVEIRA, Newton. Curso de propriedade industrial. 2. ed. São Paulo: RT, 1987.

- Garantias constitucionais aos bens imateriais. Revista de Direito Mercantil, Industrial, Econômico e Financeiro, São Paulo, ano 24 (nova série), n. 60, p. 18-23, out.-dez. 1997.

Propriedade intelectual: propriedade industrial, direito de autor, software, cultivares. 3. ed. São Paulo: Manole, 2005.

TEHRANIAN, John. Whither Copyright? Transformative Use, Free Speech, and an Intermediate Liability Proposal. Brigham Young University Law Review, Provo, n. 5, p. 1201-1260, 2005.

TINHORÃO, José Ramos. História social da música popular brasileira. São Paulo: Editora 34, 1998.

UNCTAD-ICTSD (United Nations Conference on Trade and Development, International Centre for Trade and Sustainable Development). Project on Intellectual Property Rights and Sustainable Development, Policy Discussion Paper-Intellectual Property Rights: Implications for Development. Genebra, 2003. Disponível em: <http://www.iprsonline.org/unctadictsd/policyDpaper.htm>. Acesso em: 11 jan. 2007.

VIANNA, Luiz Fernando. Geografia carioca do samba. Rio de janeiro: Casa da Palavra, 2004.

Daniel do Amaral Arbix

Secretaria de Assuntos Legislativos - Min. da Justiça Esplanada dos Ministérios, Bloco T. Min. da Justiça, $4^{\circ}$ andar, sala 426 - 70064-900 Brasília, Brasil d.arbixauol.com.br
Mestrando em direito Pela USP, Brasil

Consultor do Programa das Nações Unidas Para o DesenVolviMENTO JUNTO À SECRETARIA DE AsSuntos

LEgISLATIVOS dO MINISTÉRIO DA JUSTIÇA 